\title{
Investigation of Epidermal Growth Factor (EGF) Levels in Milk of Anatolian Buffaloes with Subclinical Mastitis
}

\author{
Hande GURLER ${ }^{* 1}$, Gül Fatma YARIM², Seçkin SALAR², Arzu FINDIK ${ }^{4}$, Ayris GOKCEOGLU², \\ Aytac AKCAY ${ }^{5}$, Ayhan BASTAN ${ }^{3}$ \\ ${ }^{1}$ Department of Obstetrics and Gynecology, Faculty of Veterinary Medicine, Ondokuz Mayns University, Turkey \\ ${ }^{2}$ Department of Biochemistry, Faculty of Veterinary Medicine, Ondokuz. Mayzs University, Turkey \\ ${ }^{3}$ Department of Obstetrics and Gynecology, Faculty of Veterinary Medicine, Ankara University, Turkey \\ ${ }^{41}$ Department of Microbiology, Faculty of Veterinary Medicine, Ondokuz. Maylbs University, Turkey \\ ${ }^{5}$ Department of Biometry, Faculty of Veterinary Medicine, Erciyes University, Turkey
}

\begin{abstract}
Subclinical mastitis (SCM) is a serious disease of farm animals. There are many studies on SCM that aim to make the diagnosis practical, economical and reliable. It was the aim of the present study comparison of epidermal growth factors (EGF) ratios in animals with and without subclinical mastitis as an indictor of SCM in Anatolian water buffaloes. A study was carried out in a total of on 35 milk samples from 20 healthy and 15 mastitic mammary quarters of clinical healthy and nonpregnant buffaloes. Samples were examined using California mastitis test (CMT) as cow side test to detect of SCM before being transferred to the laboratory. Microbiological culture was also performed to determine bacterial contamination. Level of EGF and somatic cell count (SCC) was determined in all samples. As a result of the comparison of the EGF concentration between the SCM ( +$)$ and SCM (-) groups, the SCM (+) group was found to be higher than the SCM (-) group. EGF tests may be a useful tool in determining subclinical mastitis.
\end{abstract}

Keywords: Buffalo, Epidermal growth factor, Milk, Subclinical mastitis

\author{
$* * *$ \\ Subklinik Mastitisli Anadolu Mandalarında Epidermal Büyüme Faktörü Değerlerinin (EGF) \\ Araştırılması
}

ÖZ

Subklinik mastitis (SKM), çiftlik hayvanlarının ciddi bir hastalığıdır. Subklinik mastitis tanısının pratik, ekonomik ve güvenilir olmasını amaçlayan birçok çalışma vardır. Bu çalışmada Anadolu mandalarında SKM'in bir göstergesi olarak subklinik mastitis olan ve olmayan hayvanlarda epidermal büyüme faktörleri (EGF) oranlarının karşılaştırılması amaçlanmıştır. Çalışma klinik olarak sağlıklı ve gebe olmayan 20 sağlıklı ve 15 mastitisli meme lobundan alınan toplam 35 süt örneğinde yürütülmüştür. Süt örnekleri alınır alınmaz, laboratuvara transferi gerçekleştirilmeden önce Kaliforniya mastitis test (CMT) ile saha koşullarında SKM tespiti yapıldı. Bakteriyel kontaminasyonu belirlemek amacıyla mikrobiyolojik kültür yapıldı. Tüm örneklerde EGF düzeyi ve somatik hücre sayısı (SCC) belirlendi. EGF konsantrasyonunun SKM (+) ve SKM (-) grupları arasındaki karşılaştırma sonucunda, SKM (+) grubunun SKM (-) grubundan daha yüksek olduğu bulundu. EGF testlerinin subklinik mastitisin belirlenmesinde yararlı bir araç olabileceği kanısına varılmıştır.

Anahtar Kelimeler: Epidermal büyüme faktörü, Manda, Subklinik mastitis, Süt

To cite this article: Gürler H. Yarm G.F. Salar S. Findık A. Gökçeoğlu A. Akçay A. Bastan A. Investigation of Epidermal Growth Factor (EGF) Levels in Milk of Anatolian Buffaloes with Subclinical Mastitis. Kocatepe Vet J. (2019) 12(3):254-257. 


\section{INTRODUCTION}

Epidermal growth factor is a 53-amino acid polypeptide that plays an important role in the regulation of mammary epithelial regeneration and also modulation of innate immune responses. It has biological roles including embryonic organ development, mammary morphogenesis, mammary cell proliferation and mammary development. (Fu et al. 2015, Gabadage et al. 2017).

According to International Dairy Federation (IDF) a confirmatory diagnosis of SCM recommendations is based on the microbiological status and inflammatory reactions i.e., somatic cell count $\left(\mathrm{SCC} \geq 2 \times 10^{5} \mathrm{cells} / \mathrm{ml}\right.$ of milk) of the quarter (IDF 1987). It was reported that diagnosis based on physical and chemical changes in the SCM milk is reported to be unsatisfactory and also the logistic and financial considerations involved with sampling all animals in a herd have precluded these techniques from being widely adopted. For this reason, it desirable to use alternative parameters to indicate inflammation in order to determine the health status of the mammary glands (Guha et al. 2013). It has been suggested that EGF maybe important in cows with SCM by increased expression due to inflammatory events in the mammary gland various cellular processes and tissue repair (Sheffield 1997). According the Guha et. al. (2013) one of the principles of detecting inflammation within the mammary gland is to study the mammary epithelial integrity. Increased insulin like growth hormone (IGF-1) and vascular endothelial growth factor (VEGF) levels in the mammary gland as a result infection with Staphylococcus aureus (S.aureus) causing chronic mastitis suggests that growth factors play a role in mammary gland infections (Dallard et al. 2007). However, no studies have examined the relationship between EGF and SCM.

\section{MATERIAL and METHODS}

This study was carried out in small family-type farms of Anatolian buffalo localized around the Kizilirmak delta in Samsun (latitude $41^{\circ} 34^{\prime} 16^{\prime \prime} \mathrm{N}$; longitude, $\left.35^{\circ} 51^{\prime} 56 " \mathrm{E}\right)$. The study was conducted on 35 milk samples from 20 healthy and 15 mastitic mammary quarters of clinical healthy and nonpregnant buffaloes. Teat ends were disinfected with cotton swabs with $70 \%$ alcohol, allowed to dry and the foremilks from quarters were discarded. Milk samples were collected from buffaloes with milking being done by hand. CMT was performed directly to milk samples from each quarter in the farm using the method Schalm et al. (1971). CMT was evaluated separately from four mammary quarters with negative $(-)$, suspicious $(+1),+2,+3$ and +4 (Bardakcioglu et al. 2011).
CMT positive samples were examined by bacteriological examination. For this purpose milk samples was brought to the laboratory, they were homogenized with a vortex mixer; each of them was plated on blood agar enriched with 5\% sheep blood and McConcey agar plates. The plates were incubated at $37^{\circ} \mathrm{C}$ for $24-48$ hours. Then, suspicious colonies were evaluated for cultural characteristics (haemolysis, pigmentation) and microscopy (Gram staining) (Quinn et al. 1994).

The milk EGF concentrations were determined using bovine specific ELISA kit (MBS706122, MyBioSource, Inc. San Diego, CA, USA) following the procedure as described by the manufacturer. Absorbance was measured at $450 \mathrm{~nm}$ with a microplate reader (Infinite F50, Tecan Austria GmbH, Grödig, Austria) and EGF concentrations were calculated.

To determine SCC of the milk, a composite milk sample $(50 \mathrm{ml})$ was collected from all quarters of each animal and $10 \mathrm{ml}$ milk sample placed in a sealable tube. Prior to transport of the samples to the laboratory, a chemical tablet (Microtabs), which inhibits microbial growth without affecting the SCC, was added to the each tube, as it will be one tablet for $10 \mathrm{ml}$ milk sample. The milk samples were transported to the laboratory under controlled cold chain conditions $\left(+4^{\circ} \mathrm{C}\right)$. In the laboratory, the milk samples were first heated in a $40^{\circ} \mathrm{C}$ water bath for 10 min. The SCC of each sample was then determined with device the Combi 150 (Bentley) includes a device (Somacount 150) for measuring the SCC of milk according to the manufacturer's instructions. In the evaluation of the SCC data, buffaloes with SCC below $200 \times 10^{3}$ cells $/ \mathrm{ml}$ were considered SCM (-), while above $200 \times 10^{3}$ cells $/ \mathrm{ml}$ were SCM (+) (Sharma et al. 2011).

\section{Statistical analysis}

Normal distribution of data was evaluated by Q-Q plot, histogram and Shapiro Wilk test. Kruskal Wallis and Mann Whitney $\mathrm{U}$ test were used to compare experimental groups according to EGF and SCC. The relationship between EGF and SCC was evaluated by Spearman's Rho test. NCSS 9 program was used for data analysis. The level of significance was set at $\mathrm{p}$ $<0.05$.

\section{RESULTS}

According to the results of bacterioscopy, there was a significant difference in terms of EGF between the group bacterial growth $(+)$ and bacterial growth $(-)(\mathrm{p}$ $<0.05)$. The mean of the bacterial growth $(+)(6.89 \pm$ $0.62)$ was higher than the mean of the bacterial growth (-) group (4.55 \pm 0.50$)$ (Table 1). 
There was a significant difference between the SCM $(+)$ and SCM (-) groups in terms of EGF ( $p<0.001)$. The comparison of EGF concentration between SCM (+) and SCM (-) group is shown in Table 2. SCM (+) group $(7.50 \pm 0.41)$ was higher than SCM (-) group $(3.15 \pm 0.32)$.
There was a significant difference between CMT $(+)$ and CMT $(-)$ groups in terms of EGF $(p<0.01)$. The mean of EGF (-) group was lower than that of CMT $(+2)$ and $(+3)$ group (3.15 \pm 0.32$)$ (Table 3).

A positive correlation was found between EGF and SCC $(\mathrm{r}=0.737, \mathrm{p}<0.001)$ (Table 4).

Table 1. EGF and SCC levels and statistical significance control according to bacterioscopy results

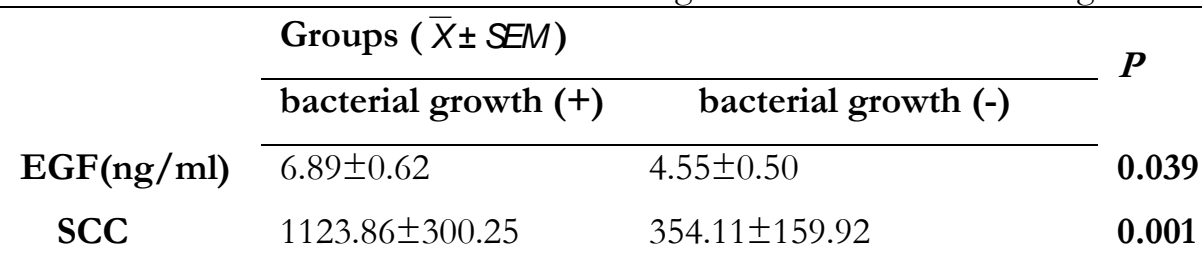

Table 2. EGF levels and statistical significance control according to subclinical mastitis

\begin{tabular}{rlll} 
& \multicolumn{2}{l}{ Groups $(\bar{X} \pm$ SEM $)$} & $P$ \\
\cline { 2 - 3 } EGF & SCM (+) & SCM (-) & $<0.001$ \\
\cline { 2 - 3 }$(\mathrm{ng} / \mathrm{ml})$ & $7.50 \pm 0.41$ & $3.15 \pm 0.32$ & \\
\hline
\end{tabular}

Table 3. EGF levels and statistical significance control according to CMT results

\begin{tabular}{|c|c|c|c|c|c|}
\hline & \multicolumn{4}{|c|}{ Groups $(\bar{X} \pm$ SEM) } & \multirow{2}{*}{$P$} \\
\hline & CMT (-) & CMT (+1) & CMT (+2) & CMT (+3) & \\
\hline $\mathrm{EGF}(\mathrm{ng} / \mathrm{ml})$ & $3.15 \pm 0.3^{a}$ & $8.57 \pm 0.65^{b}$ & $6.90 \pm 0.48^{b}$ & $7.05 \pm 0.83^{b}$ & $<0.001$ \\
\hline SCC & $33.05 \pm 4.1^{\mathrm{a}}$ & $839.20 \pm 405.38^{b}$ & $839.60 \pm 265.5^{b}$ & $1745.40 \pm 650.7^{\mathrm{b}}$ & $<0.001$ \\
\hline
\end{tabular}

Table 4. The correlation between EGF and SCC levels

\begin{tabular}{lll}
\hline Spearman's rho correlation coefficient & EGF $(\mathbf{n g} / \mathbf{m l})$ & P value \\
\hline SCC & 0,737 & $<0,001$ \\
\hline
\end{tabular}

\section{DISCUSSION}

Subclinical mastitis is the most important disease affecting the dairy sector in all farm animals. It causes high losses in the amount and quality of milk, resulting in significant economic losses (Bradley 2002, Ergun et al. 2009, Ozenc et al. 2008, Sudhan and Sharma 2010). Unlike clinical mastitis, subclinical mastitis is a herd problems and its detection is not as easy as clinical mastitis. For this reason, fast detection is very important in terms of minimizing the financial loss.

It has been reported that EGF has increased due to its role in tissue repair in cow mammary tissue with subclinical mastitis (Sheffield 1997). Epidermal growth factor (EGF) is a 53 amino acid polypeptide with biological roles such as embryonic organ development, mammary morphogenesis, mammary cell proliferation and mammary development.
Epidermal growth factor receptor (EGFR) ligands have been identified as important components in the modulation of natural immunity. It is noted that these ligands are produced by inflammatory cells, including neutrophils, eosinophils, monocytes, epithelial cells and fibroblasts, and upregulation of prostaglandin production and interleukin 1 (IL-1) in the mammary gland of intermittent animals, interleukin 8 (IL-8), tumor to participate in the production of necrosis factor and antimicrobial peptides. Both IL-1 and IL-8 have been shown to increase neutrophil flow and increased oxygen radical formation during S.aureus mastitis in ruminant animals and thus fight bacterial invasion (Gabadage et al. 2017). In this study the results confirmed our hypothesis and the increase in EGF due to inflammation in the mammary gland is thought to occur in parallel with the increase in SCC caused by inflammation. Similarly, strong positive association with bacterial growth and CMT values supports this view. In addition, it has been reported 
that cows with mastitis increase EGF expression in mammary tissue and play a potential role in tissue repair and cellular process during mastitis (Sheffield 1997). In this study, it was found that EGF levels increased in buffalo milk with subclinical mastitis compared to healthy milk.

It was reported that EGF receptor numbers increase during pregnancy in the cow (Spitzer and Grosse, 1987). And it was also stated that concentration of EGF in goat milk to be influenced by pregnancy and lactation status (Dehnhard et al. 2000). Throughout the study none of the buffaloes were pregnant. The possibility of EGF exchange due to pregnancy was eliminated in this way.

\section{CONCLUSION}

This study indicated a significant correlation between SCC, CMT and EGF concentrations in Anatolian buffalo milk with subclinical mastitis. These results revealed that milk EGF assay together with SCC could be a useful tool for laboratory diagnosis of subclinical mastitis as well as for monitoring udder health.

\section{Conflicts of interest}

The authors declare that they have no conflicts of interest.

\section{ACKNOWLEDGEMENT}

This study was supported by Ondokuz. Mayss University Research Fund (project number PYO.VET.1901.17.010)

\section{REFERENCES}

Bardakc1oglu HE, Sekin S, Oral Toplu HD. Relationship between some teat and body measurements of Holstein cows and sub-clinical mastitis and milk yield. Journal of Animal and Veterinary Advances, 2011; 10: 1735-1737.

Bradley AJ. Bovine mastitis: An evolving disease. The Veterinary Journal. 2002; 164: 117-126.

Dallard BE, Ruffino V, Heffel S, Calvinho LF. Effect of a biological response modifier on expression of growth factors and cellular proliferation at drying off. Journal of Dairy Science. 2007; 90: 2229-2240.

Ergun Y, Aslantas O, Kirecci E, Sarıbay MK, Ates AT, Ulku A, Demir C. Prevalence and etiology of SCM in awassi dairy ewes in southern Turkey. Turkish Journal of Veterinary and Animal Science. 2009; 33: 477-483.

Fu NY, Rios AC, Pal B, Soetanto R, Lun AT, Liu K, Beck T, Best SA, Vaillant F, Bouillet $P$, Strasser A, Preiss T, Smyth GK, Lindeman GJ, Visvader JE. EGF-mediated induction of Mcl-1 at the switch to lactation is essential for alveolar cell survival. Nat. Cell Biol, 2015; 17, 365-375.

Gabadage K, Chirino-Trejo,M, Campbell J, Luby C. Efficacy of recombinant bovine epidermal growth factor in the treatment of experimental subclinical Staphylococcus aureus mastitis in a ewe model. Veterinary Record Open. 2017; 4: e000179.
Guha A, Guha R, Gera S. Comparison of $\alpha 1$-antitrypsin, $\alpha 1$-acid glycoprotein fibrinogen and Nox as indicator of subclinical mastitis in riverine buffalo (Bubalus bubalis). Asian Australas. Journal of Animal Science, 2013; 26: 788-794.

IDF. Bovine Mastitis: Definition and guidelines for diagnosis. Bulletin of the International Dairy Federation, No. 211, Belgium. 1987.

Ozenc E, Vural MR, Sekeri E, Ucar M. An evaluation of SCM during lactation in Anatolian buffaloes. Turkish Journal of Veterinary and Animal Science. 2008; 32: 359-368.

Quinn PJ, Carter ME, Markey BK, Carter GR. Clinical Veterinary Microbiology. Mosby- Year Book Europe, London, 1994.

Schalm, OW, Carroll EJ, Jaire NC. Bovine mastitis. Lea and Febiger, Philadelphia, PA. 1971; 80-89.

Sharma N, Singh NK, Bhadwal MS. Relationship of somatic cell count and mastitis: An overview. Asian-Australian Journal of Animal Science, 2011; 24: 429-438.

Sheffield LG. Mastitis increases growth factor messenger ribonucleic acid in bovine mammary glands. Journal of Dairy Science. 1997; 80: 2020-2024.

Sudhan NA, Sharma N. Mastitis-An important production disease of dairy animals. SMVS' DAIRY YEAR BOOK, 2010; 72-88. 